ELORE (ISSN 1456-3010), vol. $18-1 / 2011$.

Julkaisija: Suomen Kansantietouden Tutkijain Seura ry.

[http://www.elore.fi/arkisto/1_11/kirjat_fingerroos.pdf]

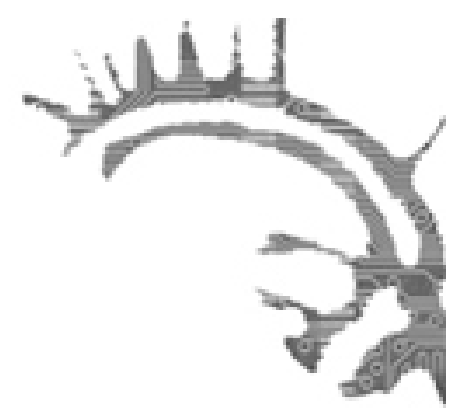

KIRJA-ARVIO

\title{
MARIA, ENSIMMÄINEN NAINEN
}

VUOLA, ELINA 2010: Jumalainen nainen. Neitsyt Mariaa etsimässä. Helsinki: Kustannusosakeyhtiö Otava. 220 sivua.

\section{$\underline{\text { Outi Fingerroos }}$}

Helsingin yliopiston Latinalaisen Amerikan tutkimuksen professorin Elina Vuolan Jumalainen nainen on tutkimus ja tietokirja Neitsyt Mariasta rikkaana historiallisena symbolina. Näkökulmana on naiseus ja naiseuteen sisältyvät ristiriidat. Vuolan mukaan sukupuoli, naiset ja naisellinen symboliikka ovat aina olleet osa kristinuskoa, mutta kristillinen teologia on usein ollut miesten määrittelemää. Kristinusko onkin ollut naista kohtaan ristiriitainen, sillä naiseen, ruumiillisuuteen ja seksuaalisuuteen on kaikkina aikoina liitetty kielteisyyttä ja uskonto on toiminut näiden asenteiden oikeuttajana. Onko Maria-symboli siis naisille myönteinen vai haitallinen esikuva ja palvonnan kohde?

Vuola paneutuu kirjansa alkupuolella Neitsyt Mariaan liittyvän kunnioituksen historiaan ja teologiaan. Uskon representaatioista kirjassa ovat esillä muiden muassa taide, kansanhurskaus ja eletty uskonnollisuus. Monet esimerkit ovat hänen kenttätyömatkoiltaan Latinalaisesta Amerikasta, jossa naisten kristillinen kansanhurskaus elää voimakkaana. Vertailua tehdään myös suomalaiseen kansanuskoon. Tutkimus yhdistää Vuolan laajan lukeneisuuden feministinä, teologina ja uskontotieteilijänä sekä Latinalaisen Amerikan tuntijana.

\section{KRISTILLINEN ÄITI}

Mariologia tarkoittaa oppia Neitsyt Mariasta. Tämän opin ytimessä on kristillinen usko ja traditio, erityisesti tietenkin kristillinen teologia. Sen sisällöt vaihtelevat kirkkokunnittain. Näitä näkemyksiä Vuola esittelee kirjansa alkupuolella. Katolisessa kirkossa Neitsyt Marialla on merkittävä teologinen asema ja Mariaan kietoutuva uskonnollinen kultti on monipuolinen ja elävä. Maria on katolisen kirkon huomattavin jäsen, kans- 
sapelastaja ja armon välittäjä. Myös ortodokseille Maria on Pyhän Hengen täyttämä esikuvallinen ihminen, jonka kautta välittyy armoa ja jota kunnioitetaan. Katolisuutta ja ortodoksisuutta yhdistääkin se piirre, että Marialle annetaan teologiassa, liturgiassa ja kansanhurskaudessa suuri merkitys. Suurin opillinen ero on se, että ortodoksit kunnioittavat Mariaa mutta häntä ei palvota.

Protestanttisten kirkkojen suhde Mariaan sen sijaan ei ole yhtä tiivis ja teologisesti paalutettu. Marian kunnioittaminen ja rukoilu eivät ole protestanttisenkaan teologian mukaan harhaoppia, mutta opillisesti Neitsyen ympärille ei ole rakentunut yhtä voimakasta mariologiaa kuin katolisessa ja ortodoksisessa teologiassa. Myös juutalaisuus ja islam tuntevat Marian. Juutalaisille Maria on usein kuitenkin vain tavallinen uskova nainen, jonka poika Jeesus sai aikaan suuria mutta kärsi kuoleman roomalaisten valloittajien käsissä. Islamin Maria puolestaan on tunnustettu, kunnioitettukin henkilö, joka on läsnä Koraanissa. Hänen ympärilleen ei kuitenkaan ole syntynyt kulttia. Vuola kirjoittaakin, että Maria on sekä läsnä että poissa näiden kolmen sisaruskonnon parissa.

Mariaan tiivistyy paljon sellaista, jonka kristillinen kulttuuri mieltää hyväksi naisellisuudeksi: Mariaan kätkeytyy pyhä, jumalallinen viisaus (Sofia), ja hän symboloi kirkkoa Kristuksen morsiamena ja uskovien äitinä. Maria ei langennut syntiin kuten Eeva, eikä hän ollut petturi ja pahan äiti, kuten intiaanityttö Malinche, joka toimi Meksikon valloittajan Hernán Cortésin tulkkina ja jalkavaimona synnyttäen maailmaan huoranpenikan eli mestitson. Katolinen Maria on myös välittäjä ihmisten ja jumalallisen välillä. Kansanhurskaudessa hän onkin usein ensimmäinen nainen, jota rukoillaan ja jolta odotetaan ihmeitä. Hänellä on äidillinen suhde poikaansa, joten uskovilla on mahdollisuus päästä äitinsä välityksellä lähemmäs jumaluutta.

\section{VAiHTOehtojen ja Ristirittojen Maria}

Feministien ajatukset ja uudelleentulkinnat Marian sukupuolesta ja ruumiillisuudesta, neitsyydestä, esikuvallisuudesta ja jumalallisuudesta ovat tutkimuksessa vastapaino opillisten tulkintojen esittelylle. Vuola kysyykin heti tutkimuksensa alussa, mikä on Marian kunnioituksen ja naisten aseman välinen suhde. Tutkimuksessaan hän todentaa, että Neitsyt Maria on uskoville naisille yhtä aikaa sekä palvottava ikoni että peili, jota kautta oma elämä näyttäytyy merkityksellisenä. Samalla hän tekee selväksi sen, että Mariaan liittyvä symbolinen feminiinisyys ei ole vain passiivista hoivaa ja herkkyyttä vaan aktiivista, elävää uskontoa. Etenkin kansanhurskaudessa Maria-usko on kaikkina aikoina saanut uusia muotoja, synkretisoitunut ja taipunut naisten elämän tarpeisiin.

Kirjan ehdottomasti parasta antia on kuitenkin laaja ja asiantuntemuksella kirjoitettu luku "Neitsyt Maria Latinalaisessa Amerikassa". Käsittelyssä käy selväksi, että Maria ei ole alueen katolisessa kulttuurissa kaapissa piilossa. Kun Kolumbus purjehti mantereelle Maria-nimisellä lippulaivalla, Maria-kulttia käytettiin alueen alkuperäiskansojen käännytyksessä yhdistävänä symbolina. Sen jälkeen Neitsyen kultti on saanut aivan omia muotojaan. Monet Latinalaisen Amerikan Mariat ovat tummahipiäisiä La Morenitoja ja etääntyneet symboliikassaan kauas eurooppalaisista ilmestyksistä.

Tunnetuin synkretistisistä Maria-hahmoista on Guadalupen Neitsyt, joka on Mek- 
sikon kansallispyhimys ja suojelija. Meksikon valtiolle ja katoliselle kirkolle Neitsyt on ensimmäinen nainen ja isänmaan symboli, jonka päivää vietetään 12. joulukuuta näyttävästi ympäri Meksikon. Meksikolaiset suhtautuvat Guadalupeen kuin lempeään äitiin: jokaisella - intiaaneilla, mestitsoilla ja valkoisilla espanjalaisilla - on tarinansa kerrottavanaan. Guadalupen Neitsyen symboliikassa on nähty vanhan intiaaniuskonnon ja katolilaisuuden yhtymäkohtia, ja Guadalupen Neitsyen voi ajatella olevan myös sosiaalisen tasa-arvon symboli, sillä Neitsyt ilmestyi köyhälle atsteekki-intiaanille mutta on samalla katolinen Madonna. Tarinaa neitsyestä onkin eri vuosisatoina käytetty poliittisesti hyväksi yhtenäistettäessä heterogeenista kansaa.

Erityisen kiinnostavaa luettavaa ovat myös ristiriitoja ratkovien "vaihtoehtoMarioiden" kultit. Esimerkiksi Guadalupe toimi Meksikon itsenäistymistaistelun symbolina; nykyisin hän kantaa asevyötä Chiapasin ja Oaxacan alkuperäiskansojen ihmisoikeustaistelussa. Vastaavalla tavalla Latinalaisen Amerikan köyhät turvautuvat Mariaan vapauttajana. Alueella puhutaan jopa "vapautuksen mariologiasta," jossa Maria on köyhän kansan, erityisesti naisten edustaja ja puolestapuhuja.

\section{KansanhursKaUden MARIAN SEKÄ-ETTÄ-LUONNE}

Tutkimuksen loppupuoli keskittyy Suomen ja lähialueiden kansanperinteeseen ja -hurskauteen. Vuola löytää pohjoisen Euroopan ja Latinalaisen Amerikan Marioiden kunnioituksesta yllättäviä yhtäläisyyksiä. Karjalan Maaria on samaan tapaan emoloista ensimmäinen kuin meksikolaisten Guadalupe. Myös karjalaisille naisille Maria tarjosi samastumisen kohteen ollen sekä sankari että prototyyppinen äiti, joka oli läsnä muun muassa synnytyksissä sekä vertaisena naisena että yliluonnollisena kätilönä.

Vuola kirjoittaa monessa kohdassa Marian sekä-että-luonteesta. Käsitteellinen vertaus avautuu parhaiten juuri naisten synnytyksen kokemuksen avulla: kansanhurskauden Maria on sekä kanssakokija (synnyttävä nainen) että esikuvallinen auttaja (jumalallinen nainen). Marian sekä-että-luonne siis asettaa hänet yhtäältä ihmiseksi ihmisten joukkoon, toisaalta jumalalliseksi naiseksi taivaan ja maan välille. Vuola kirjoittaakin oivallisena johtopäätöksenään, että "Kansanuskon imitatio Mariae naisten eettisenä ihanteena ja ajatus naiseuden ja jumaluuden yhteen liittämisen tärkeydestä edustavat mahdollista uudenlaista Maria-tulkintaa. Ne myös esittävät vaihtoehtoisen tavan ajatella inkarnaatiota, Jumalan ihmiseksi tulemista.” (s. 195.)

Kokonaisuutena Jumalainen Nainen on ansiokas ja asiantunteva tutkimus. Se on kirjoitettu hyvällä suomen kielellä, eikä tekijä viljele hankalaa feminististä puheenpartta kuin paikoin. Tutkimus osoittaa elävästi, että Maria on moniulotteinen, rikas ja ristiriitainen symboli, josta kristillinen perinne ei tarjoa vain yhtä samastumisen mallia. Tutkimus myös rinnastaa hienosti Mariaan liittyvät opetukset ja eletyn kansanhurskauden.

Dosentti Outi Fingerroos on yliopistotutkija Jyväskylän yliopiston Monikulttuurisuus ja vuorovaikutus -osaamiskeskuksessa. 